\title{
KESEDIAAN GURU SAINS SEKOLAH RENDAH TERHADAP PELAKSANAAN DUAL LANGUANGE PROGRAMME (DLP)
}

\author{
${ }^{1}$ Norhisham Shamsudin, ${ }^{2}$ Norazilawati Abdullah, ${ }^{3}$ Noraini Mohamed Noh \\ ${ }^{1,2,3}$ Fakulti Pembangunan Manusia, Universiti Pendidikan Sultan Idris \\ ${ }^{2}$ Pusat Penyelidikan Perkembangan Kanak-Kanak Negara (NCDRC) \\ 35900 Tanjong Malim, Perak
}

Received : 03 Febuari 2018; Accepted : 12 Mei 2018; Published : 26 Jun 2018

\begin{abstract}
ABSTRAK
Kajian ini dijalankan untuk mengenal pasti tahap kesediaan guru dalam melaksanakan DLP(Dual Languange Programme) dalam kalangan guru-guru Sains. Reka bentuk kajian menggunakan kaedah kuantitatif, menggunakan instrumen borang soal selidik bagi mendapatkan respon. Sampel seramai 103 guru Sains dipilih secara rawak dari sekolah-sekolah daerah Petaling Utama. Data yang dikumpulkan telah dianalisis menggunakan perisian Statistical Package For Social Sciences (SPSS). Secara deskriptif, data dianalisis menggunakan taburan kekerapan, peratus, min dan sisihan piawaian. Dapatan kajian menunjukkan tahap kesediaan guru dari segi kemahiran (penguasaan bahasa Inggeris dan istilah Sains) terhadap pelaksanaan DLP adalah sederhana, tahap kesediaan guru Sains dari segi pengetahuan terhadap pelaksanaan DLP adalah tinggi dan tahap kesediaan minat terhadap pelaksanaan DLP adalah sederhana. Analisis inferensi berdasarkan analisis kolerasi yang telah dijalankan tidak terdapat hubungan yang signifikan antara tahap kesediaan guru dan pengalaman mengajar Sains sekolah rendah dalam melaksanakan DLP. Semua pihak seharusnya memainkan peranan bersama bagi memastikan pelaksanaan DLP ini akan lebih berjaya di masa akan datang.
\end{abstract}

Kata kunci Kesediaan, DLP (Dual Languange Programme), Guru Sains.

\begin{abstract}
This study was conducted to identify the level of readiness of teachers in implementing DLP (Dual Language Programme) among Science teachers. The design of the study uses quantitative methods, where the questionnaire is distributed to obtain the response. Samples of 103 Science teachers were randomly selected from the Petaling Utama districts. The data collected were analyzed using the statistical analysis method in the Statistical Package For Social Sciences (SPSS) software. Descriptively, the data were analyzed using frequency, percentage, mean and standard deviation. The findings show
\end{abstract}


that the level of readiness of teachers in terms of skills (English proficiency and Science terms) on the implementation of DLP is moderate, the level of readiness of Science teachers in terms of knowledge of DLP implementation is high and the level of enthusiasm for the implementation of DLP is moderate. Based on the correlation analysis that has been conducted there is no significant relationship between the level of readiness of teachers and the teaching experience of primary science in implementing DLP. All parties should play a joint role to ensure the implementation of this DLP will be more successful in the future.

Keywords $\quad$ Readiness, Dual Language Programme (DLP), Science Teachers.

\section{PENGENALAN}

Dual Language Programme (DLP) adalah program yang diperkenalkan di bawah dasar Memartabatkan Bahasa Malaysia Memperkukuh Bahasa Inggeris (MBMMBI) dimana ianya telah diluluskan dalam Mesyuarat Majlis Ekonomi Negara Bil. 21/2015 pada 13 Oktober 2015 dan diumumkan oleh YAB Perdana Menteri Malaysia dalam pembentangan bajet 2016 pada 23 Oktober 2015 yang memberi pilihan kepada sekolah-sekolah yang memenuhi kriteria untuk mengadakan sesi pengajaran dan pembelajaran dalam bahasa Inggeris sepenuhnya selain daripada bahasa Malaysia bagi mata pelajaran Matematik, Sains, Teknologi Maklumat dan Komunikasi, serta Reka Bentuk dan Teknologi. (JPN Selangor, 2015)

"Pelaksanaan DLP bertujuan menyokong penguasaan kemahiran berbahasa Inggeris murid melalui peningkatan masa pendedahan terhadap bahasa Inggeris secara tidak langsung dalam Pengajaran dan Pembelajaran mata pelajaran terbabit selaras dengan Pelan Pembangunan Pendidikan Malaysia (PPPM) 2013-2025 untuk melahirkan murid yang mempunyai kemahiran dwibahasa," (Utusan Malaysia, 11 Januari 2016)

Objektif program ini adalah untuk memberi peluang kepada murid untuk meningkatkan akses dan penerokaan pelbagai ilmu untuk bersaing di peringkat global serta meningkatkan kebolehpasaran murid di alam pekerjaaan. Program ini dapat membantu dan menarik minat murid yang ingin meneruskan pengajian dalam bidang Sains, Teknologi, Kejuruteraan dan Matematik (STEM) di peringkat tertiari. (JPN Melaka, 2015)

Selaras dengan aspirasi PPPM agar murid menguasai kemahiran dwibahasa, DLP memberi peluang kepada murid untuk mengguna pakai bahasa Inggeris melalui mata pelajaran Matematik, Sains, Teknologi Maklumat dan Komunikasi, serta Reka Bentuk dan Teknologi. DLP membolehkan masyarakat Malaysia meningkatkan akses bagi penerokaan pelbagai ilmu untuk bersaing di peringkat global. (JPN Selangor, 2015)

Sekolah diupayakan untuk membuat pilihan berdasarkan kriteria yang telah digariskan. Sekolah boleh mengemukakan permohonan kepada PPD dan JPN. Pelaksanaan DLP adalah tertakluk kepada kelulusan Kementerian berlandaskan kesediaan sekolah. (JPN Selangor, 2015) 


\section{PENYATAAN MASALAH}

Input utama pembelajaran yang berkesan bergantung kepada penyampaian dan komunikasi guru dalam kelas (Mok, 2003). Sekiranya guru tidak dapat menyampaikan pengajaran dengan efektif maka timbul situasi yang menjadikan pelajar pasif semasa proses pengajaran dan pembelajaran, sentiasa bimbang, tidak yakin dan tidak bermotivasi (Nur 'Ashikin Najmuddin, 2004). Justeru itu, kajian mengenai kesediaan guru perlu dijalankan bagi mengenalpasti tahap kesediaan mereka untuk menjalankan proses pengajaran dam pembelajaran mata pelajaran Sains dalam DLP.

Masalah utama yang dihadapi oleh guru ialah tidak dapat menguasai Bahasa Inggeris dengan baik dalam pengajaran mereka (Utusan Online, 11 Julai 2009). Guru seharusnya sudah mempunyai kemahiran yang mencukupi dan keyakinan diri yang sepenuhnya untuk melaksanakan program "Dual Language Programme (DLP)" ini.

Pendedahan tentang mata pelajaran yang hendak diajar dengan menggunakan bahasa Inggeris juga masih belum mencukupi bagi sebahagian guru Sains. Penggunaan bahasa Inggeris dalam mata pelajaran Sains juga dikhuatiri mengakibatkan berlakunya salah tafsir maksud dan istilah apabila tahap Bahasa Inggeris guru cetek (Seth \& Umi Mardhiah, 2008).

Apabila guru tersalah menggunakan bahasa atau istilah, ini akan menimbulkan masalah dari segi keberkesanan pengajaran dan pembelajaran. Oleh sebab itu, penting bagi guru-guru untuk meningkatkan pengetahuan dan kemahiran mereka dalam membina keyakinan untuk menyampaikan satu pengajaran sains yang berkesan.

Tambahan pula guru-guru tidak diberikan latihan mengajar Sains dalam DLP bagi tahun 2016 kerana sekolah yang terpilih adalah sekolah yang bersedia untuk uji rintis. ELTC akan membantu dengan menjalankan program latihan peningkatan profiensi Bahasa Inggeris dalam kalangan guru yang mengikuti DLP pada tahun 2017 dan tahun berikutnya (JPN Selangor, 2015)

Justeru itu, kajian ini dijalankan bertujuan untuk meninjau kesediaan guruguru Sains untuk mengajar dalam bahasa Inggeris bagi program DLP ini. Kajian ini memberi perhatian kepada tahap pengetahuan kandungan mata pelajaran dan istilah sains serta penguasaan bahasa Inggeris guru.

\section{OBJEKTIF KAJIAN}

Objektif kajian ini adalah seperti berikut :

1. Mengenal pasti tahap kesediaan guru sains dari segi kemahiran (penguasaan dan istilah Sains dalam Bahasa Inggeris) terhadap DLP.

2. Mengenal pasti tahap kesediaan guru sains dari segi pengetahuan terhadap DLP.

3. Mengenal pasti tahap kesediaan guru sains dari segi minat terhadap DLP.

4. Mengenal pasti sama ada terdapat hubungan yang signifikan antara kesediaan guru sains dari segi kemahiran, pengetahuan dan minat dengan pengalaman mengajar Sains sekolah rendah dalam melaksanakan DLP. 


\section{HIPOTESIS KAJIAN}

$\mathrm{Ho}^{1}$ : Tidak terdapat hubungan yang signifikan antara kesediaan guru sains dari segi kemahiran (penguasaan dan istilah Sains dalam Bahasa Inggeris) dengan pengalaman mengajar sekolah rendah dalam melaksanakan DLP.

$\mathrm{Ho}^{2}$ : Tidak terdapat hubungan yang signifikan antara kesediaan guru sains dari segi pengetahuan dengan pengalaman mengajar sekolah rendah dalam melaksanakan DLP.

$\mathrm{Ho}^{3}$ : Tidak terdapat hubungan yang signifikan antara kesediaan guru sains dari segi minat dengan pengalaman mengajar sekolah rendah dalam melaksanakan DLP.

\section{KERANGKA KONSEPTUAL KAJIAN}

Kajian ini menggunakan kerangka teori model reflektifWallace(1991) yang berpendapat bahawa seseorang guru biasanya mempunyai pengetahuan dan pengalaman sedia ada yang berkaitan dengan bidang tugasnya. Apabila mengikuti latihan profesional, seseorang guru itu akan mengaitkan pengetahuan yang diterimanya (received knowledge) dengan pengetahuan melalui pengalaman (experiental knowledge) yang merupakan dua sumber pengetahuan penting dalam latihan profesional. Kedua-dua sumber pengetahuan tersebut mengikut Wallace saling bergantung antara satu sama lain bagi membolehkan guru lebih bersedia untuk melaksanakan tugas profesionalnya.

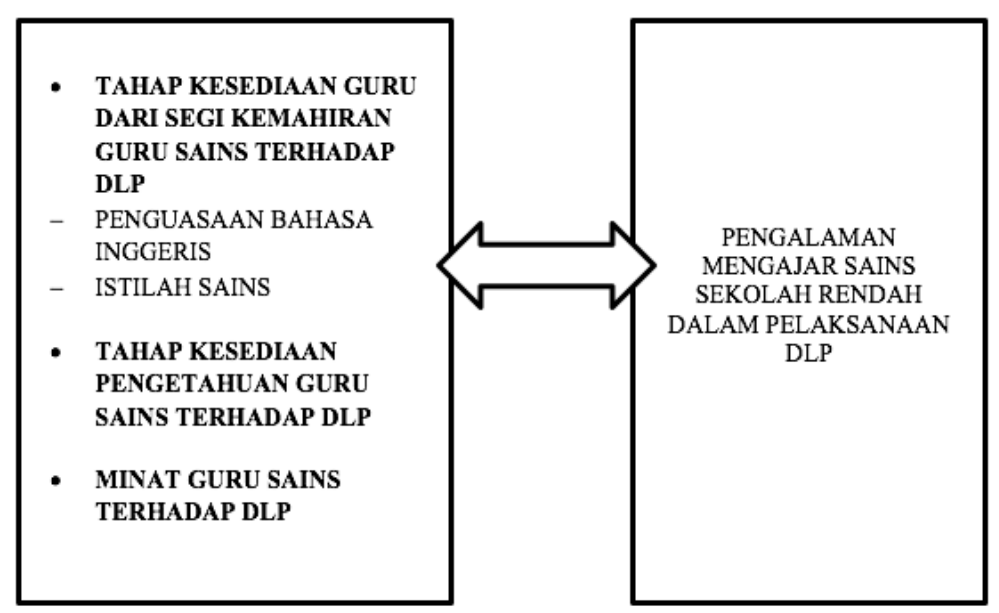

Rajah 1 Kerangka Konsep 


\section{METADOLOGI KAJIAN}

Kajian ini adalah secara kuantitatif dengan menggunakan kaedah tinjauan dimana instrumen soal selidik digunakan untuk mengetahuai tahap kesediaan guru-guru Sains dalam melaksanakan DLP. Soal selidik menggunakan Skala Likert 1 hingga 5 adalah hasil pengubahsuaian instrumen Norisah (2016) dan penambahbaikan daripada pengkaji sendiri berdasarkan objektif yang hendak dicapai. Terdapat 12 sekolah yang melaksanakan DLP di Daerah Petaling Utama, Selangor. Populasi kajian adalah seramai 140 orang guru Sains manakala seramai 100 orang guru telah dipilih secara rawak mudah sebagai sampel kajian. Kajian rintis telah dijalankan untuk mendapatkan kebolehpercayaan instrumen bagi menggambarkan indeks ketekalan setiap item. 20 orang guru yang terlibat dalam kajian rintis ini tidak terlibat dalam kajian sebenar. Nilai pekali alpha cronbach kajian ini adalah adalah 0.91. Nilai tersebut memenuhi piawai yang tinggi dan dapat digunakan untuk kajian sebenar.

Data kajian ini dianalisis dengan mengunakan perisian Statistical Package Social Science (SPSS) versi 20.0. Bagi menjawab persoalan kajian yang pertama, kedua dan ketiga, analisis secara statistik deskriptif digunakan kerana ia dapat memerihalkan data tersebut dalam nilai skor min. Analisis tersebut perlu untuk menilai tahap kesediaan guru dari segi pengetahuan, kemahiran dan minat terhadap pelaksanaan DLP. Analisis Korelasi Pearson pula dilakukan untuk mengkaji tahap hubungan antara dua pembolehubah bagi menjawab persoalan keempat.

\section{DAPATAN KAJIAN}

\section{Demografi responden}

Jadual 1 di bawah menunjukkan analisis latar belakang responden secara peratusan dan kekerapan.

Jadual 1 Analisis latar belakang responden secara peratusan dan kekerapan

\begin{tabular}{|c|c|c|c|}
\hline \multicolumn{2}{|c|}{ Pembolehubah } & Kekerapan & Peratusan (\%) \\
\hline \multirow{3}{*}{ Jantina } & Lelaki & 23 & 22.3 \\
\cline { 2 - 4 } & Perempuan & 80 & 77.7 \\
\hline \multirow{5}{*}{ Umur } & $21-30$ Tahun & 36 & 35.0 \\
\cline { 2 - 4 } & $31-40$ Tahun & 47 & 45.6 \\
\cline { 2 - 4 } & $41-50$ Tahun & 16 & 15.5 \\
\cline { 2 - 4 } & $\begin{array}{c}\text { Lebih dari 50 } \\
\text { Tahun }\end{array}$ & 4 & 3.9 \\
\hline
\end{tabular}




\begin{tabular}{|c|c|c|c|}
\hline \multicolumn{2}{|c|}{ Pembolehubah } & Kekerapan & Peratusan (\%) \\
\hline \multirow{4}{*}{\begin{tabular}{c} 
SPM \\
\multirow{4}{*}{$\begin{array}{c}\text { Kelulusan aka- } \\
\text { demik tertinggi }\end{array}$}
\end{tabular}} & $\begin{array}{c}\text { Diploma } \\
\text { Muda }\end{array}$ & 8 & 0 \\
\cline { 2 - 4 } & Ljazah Sarjana & 10 & 82.5 \\
\cline { 2 - 4 } & Lain-lain & 0 & 9.7 \\
\hline \multirow{3}{*}{$\begin{array}{c}\text { Pengalaman } \\
\text { mengajar }\end{array}$} & Bawah 5 Tahun & 22 & 0 \\
\cline { 2 - 4 } & 6-10 Tahun & 56 & 21.4 \\
\cline { 2 - 4 } & Lebih 10 Tahun & 25 & 54.4 \\
\hline
\end{tabular}

\section{Analisis Deskriptif}

Analisis secara deskriptif dijalankan untuk meneliti tahap kesediaan guru Sains terhadap pelaksanaan DLP di sekolah-sekolah rendah dari aspek pengetahuan, kemahiran dan minat guru tersebut. Jadual 2 di bawah merumuskan kesediaan guru dari aspek kemahiran, pengetahuan dan minat dalam bentuk min dan sisihan piawai.

Jadual 2 Tahap Kesediaan Guru Sains Dalam Bentuk Min dan Sisihan Piawai

\begin{tabular}{|c|c|c|}
\hline Pembolehubah & Min & Sisihan Piawai \\
\hline Kemahiran & 3.24 & 0.67 \\
\hline Pengetahuan & 3.97 & 0.55 \\
\hline Minat & 3.44 & 0.65 \\
\hline
\end{tabular}

Data di dalam jadual 3, jadual 4 dan jadual 5 menunjukkan pembolehubah bersandar yang digunakan dalam kajian ini. Nilai skor min bagi pembolehubah kemahiran adalah sebanyak 3.24 dengan sisihan piawai 0.67. Ini menggambarkan tahap kemahiran responden dalam kajian ini adalah sederhana. Nilai skor min bagi pengetahuan pula adalah sebanyak 3.97 dengan sisihan piawai 0.55 . Nilai ini menggambarkan pengetahuan responden terhadap pelaksanaan DLP adalah tinggi. Manakala nilai skor min bagi minat adalah 3.44 dengan sisihan piawai 0.65 , yang juga menggambarkan responden mempunyai minat yang sederhana terhadap perlaksanaan DLP.

Jadual 3 Kemahiran Guru Terhadap Pelaksanaan DLP

\begin{tabular}{|c|l|c|c|}
\hline Bil. & \multicolumn{1}{|c|}{ Pernyataan } & Min & $\begin{array}{c}\text { Sisihan } \\
\text { Piawai }\end{array}$ \\
\hline 1. & $\begin{array}{l}\text { Saya dapat bercakap Bahasa Inggeris dalam } \\
\text { sebutan yang betul. }\end{array}$ & 3.59 & 0.49 \\
\hline 2. & $\begin{array}{l}\text { Saya boleh menerangkan proses sains dalam } \\
\text { Bahasa Inggeris dengan baik. }\end{array}$ & 2.96 & 0.66 \\
\hline
\end{tabular}




\begin{tabular}{|c|l|c|c|}
\hline Bil. & \multicolumn{1}{|c|}{ Pernyataan } & Min & $\begin{array}{c}\text { Sisihan } \\
\text { Piawai }\end{array}$ \\
\hline 3. & $\begin{array}{l}\text { Apabila mendapat bahan rujukan dalam Bahasa } \\
\text { Inggeris, saya akan membacanya berulang kali } \\
\text { untuk memahaminya. }\end{array}$ & 2.92 & 0.48 \\
\hline 4. & $\begin{array}{l}\text { Saya boleh menyoal dalam Bahasa Inggeris } \\
\text { dengan baik. }\end{array}$ & 3.35 & 0.68 \\
\hline 5. & $\begin{array}{l}\text { Saya sentiasa menggunakan Bahasa Inggeris } \\
\text { apabila berbincang dengan pelajar di kelas. }\end{array}$ & 3.47 & 0.78 \\
\hline 6. & $\begin{array}{l}\text { Saya lebih mudah memberi pendapat dalam } \\
\text { Bahasa Melayu berbanding Bahasa Inggeris. }\end{array}$ & 3.61 & 0.93 \\
\hline 7. & $\begin{array}{l}\text { Saya kurang yakin memberi penerangan dalam } \\
\text { Bahasa Inggeris. }\end{array}$ & 2.89 & 0.61 \\
\hline 8. & $\begin{array}{l}\text { Saya tidak berapa selesa apabila diajukan soa- } \\
\text { lan dalam Bahasa Inggeris. }\end{array}$ & 3.25 & 0.61 \\
\hline 9. & $\begin{array}{l}\text { Saya tidak perlu merujuk buku sains dalam } \\
\text { Bahasa Inggeris kerana dalam Bahasa Melayu } \\
\text { mudah diperolehi. }\end{array}$ & 3.26 & 0.74 \\
\hline 10. & $\begin{array}{l}\text { Saya biasa menggunakan Bahasa Inggeris den- } \\
\text { gan rakan sejawat yang lain }\end{array}$ & 3.08 & $\mathbf{3 . 2 4}$ \\
\hline & SEDERHANA keseluruhan & 0.72 \\
\hline
\end{tabular}

Jadual 4 Pengetahuan Guru Terhadap Pelaksanaan DLP

\begin{tabular}{|c|l|c|c|}
\hline Bil. & \multicolumn{1}{|c|}{ Pernyataan } & Min & $\begin{array}{c}\text { Sisihan } \\
\text { Piawai }\end{array}$ \\
\hline 1. & Konsep DLP amat mudah untuk difahami & 3.98 & 0.59 \\
\hline 2. & $\begin{array}{l}\text { Pendedahan yang diberikan kepada saya sudah } \\
\text { mencukupi. }\end{array}$ & 3.56 & 0.64 \\
\hline 3. & $\begin{array}{l}\text { Pengalaman saya menjalankan PPSMI mem- } \\
\text { bantu saya melaksanakan DLP }\end{array}$ & 3.66 & 0.95 \\
\hline 4. & $\begin{array}{l}\text { Saya dapat menguasai DLP dengan mudah dan } \\
\text { cepat }\end{array}$ & 3.74 & 0.59 \\
\hline 5. & $\begin{array}{l}\text { Buku panduan DLP membantu saya dalam } \\
\text { mempelajari sistem tersebut. }\end{array}$ & 3.88 & 0.51 \\
\hline 6. & $\begin{array}{l}\text { Bahan rujukan mengenai DLP perlu diedar ke } \\
\text { setiap sekolah. }\end{array}$ & 4.67 & 0.47 \\
\hline 7. & $\begin{array}{l}\text { Masih banyak yang perlu saya pelajari menge- } \\
\text { nai DLP }\end{array}$ & 4.59 & 0.49 \\
\hline 8. & $\begin{array}{l}\text { Saya tahu cara merekod hasil kerja murid } \\
\text { dalam pelaksanaan DLP. }\end{array}$ & 3.75 & 0.44 \\
\hline
\end{tabular}




\begin{tabular}{|c|l|c|c|}
\hline Bil. & \multicolumn{1}{|c|}{ Pernyataan } & Min & $\begin{array}{c}\text { Sisihan } \\
\text { Piawai }\end{array}$ \\
\hline 9. & $\begin{array}{l}\text { DLP meningkatkan pengetahuan saya untuk } \\
\text { mengajar subjek Sains. }\end{array}$ & 4.16 & 0.36 \\
\hline 10. & Bahan Rujukan DLP mudah difahami. & 3.66 & 0.48 \\
\hline \multicolumn{2}{|c|}{ Min keseluruhan } & $\mathbf{3 . 9 7}$ TINGGI \\
\hline
\end{tabular}

Jadual 5 Minat Guru Terhadap Pelaksanaan DLP

\begin{tabular}{|c|l|c|c|}
\hline Bil. & \multicolumn{1}{|c|}{ Pernyataan } & Min & $\begin{array}{c}\text { Sisihan } \\
\text { Piawai }\end{array}$ \\
\hline 1. & $\begin{array}{l}\text { Saya bersedia untuk melaksanakan DLP di } \\
\text { sekolah. }\end{array}$ & 3.85 & 0.56 \\
\hline 2. & Saya menyokong pelaksanaan DLP di sekolah. & 3.93 & 0.49 \\
\hline 3. & $\begin{array}{l}\text { Saya bersedia untuk memikul tanggungjawab } \\
\text { mentaksir murid dalam pelaksanaan DLP. }\end{array}$ & 3.70 & 0.62 \\
\hline 4. & DLP perlu diteruskan. & 3.66 & 0.75 \\
\hline 5. & DLP meningkatkan beban kerja saya. & 3.49 & 0.66 \\
\hline 6. & $\begin{array}{l}\text { Saya perlu bekerja lebih masa untuk melak- } \\
\text { sanakan DLP. }\end{array}$ & 3.43 & 0.64 \\
\hline 7. & $\begin{array}{l}\text { Pendedahan yang diberikan kepada saya sudah } \\
\text { mencukupi. }\end{array}$ & 3.33 & 0.62 \\
\hline 8. & $\begin{array}{l}\text { Saya yakin untuk menjalankan kursus dan lati- } \\
\text { han kepada pihak lain mengenai DLP. }\end{array}$ & 2.86 & 0.70 \\
\hline 9. & $\begin{array}{l}\text { DLP lebih baik dan berkesan berbanding } \\
\text { dengan pembelajaran dalam Bahasa Melayu } \\
\text { sepenuhnya. }\end{array}$ & 2.92 & 0.86 \\
\hline 10. & $\begin{array}{l}\text { Saya dapat menguasai DLP dengan mudah dan } \\
\text { cepat. }\end{array}$ & 3.42 & 0.65 \\
\hline & Min keseluruhan & SEDERHANA \\
\hline
\end{tabular}

\section{Analisis Inferensi}

Analisis inferensi dijalankan untuk mencari hubungan di antara kesediaan guru Sains dari segi kemahiran (penguasaan dan istilah Sains dalam Bahasa Inggeris), pengetahuan dan minat dan pengalaman mengajar guru sekolah rendah dalam melaksanakan DLP. 
Jadual 6 Analisis Kolerasi Antara Kesediaan Guru Sains Dari Segi Kemahiran, Pengetahuan Dan Minat Dengan Pengalaman Mengajar Sekolah Rendah Dalam Melaksanakan DLP

\begin{tabular}{|c|l|c|c|c|l|}
\hline \multirow{2}{*}{ Bil } & \multirow{2}{*}{$\begin{array}{c}\text { Komponen } \\
\text { Kesediaan } \\
\text { Guru }\end{array}$} & \multicolumn{2}{|c|}{$\begin{array}{c}\text { Pengalaman Mengajar Sekolah Rendah } \\
\text { Dalam Melaksanakan DLP }\end{array}$} & \multirow{2}{*}{ Hubungan } \\
\cline { 3 - 5 } & & $\begin{array}{c}\text { Nilai Pekali } \\
(\mathbf{r})\end{array}$ & $\begin{array}{c}\text { Nilai Pekali } \\
\text { Penentuan } \\
\mathbf{( r}^{\mathbf{2}}\end{array}$ & Sig. & \\
\hline 1 & Kemahiran & 0.078 & 0.006 & 0.434 & Sangat Lemah \\
\hline 2 & Pengetahuan & 0.062 & 0.004 & 0.536 & Sangat Lemah \\
\hline 3 & Minat & 0.055 & 0.003 & 0.582 & Sangat Lemah \\
\hline
\end{tabular}

Keputusan analisis Kolerasi Pearson untuk melihat hubungan kesediaan guru sains daripada segi kemahiran dengan pengalaman mengajar Sains dalam pelaksanaan DLP mendapati bahawa keputusan yang diperolehi daripada analisis yang dijalankan ialah $[\mathrm{r}=0.078, \mathrm{p}=0.434>0.05]$. Ini menunjukkan tidak terdapat hubungan yang signifikan antara kemahiran dengan pengalaman mengajar guru Sains dalam pelaksanaan DLP. Maka dapatlah disimpulkan bahawa Hol adalah diterima kerana tidak terdapat hubungan yang signifikan antara kemahiran dengan pengalaman mengajar guru sains dalam perlaksanaan DLP.

Keputusan analisis Kolerasi Pearson untuk melihat hubungan kesediaan guru sains daripada segi pengetahuan dengan pengalaman mengajar Sains dalam pelaksanaan DLP mendapati bahawa keputusan yang diperolehi daripada analisis yang dijalankan ialah $[\mathrm{r}=0.062, \mathrm{p}=0.536>0.05]$. Ini menunjukkan tidak terdapat hubungan yang signifikan antara pengetahuan dengan pengalaman mengajar guru Sains dalam pelaksanaan DLP. Maka dapatlah disimpulkan bahawa Ho2 adalah diterima kerana tidak terdapat hubungan yang signifikan antara pengetahuan dengan pengalaman mengajar guru sains dalam perlaksanaan DLP.

Keputusan analisis Kolerasi Pearson untuk melihat hubungan kesediaan guru sains daripada segi minat dengan pengalaman mengajar Sains dalam pelaksanaan DLP mendapati bahawa keputusan yang diperolehi daripada analisis yang dijalankan ialah $[\mathrm{r}=0.055, \mathrm{p}=0.582>0.05]$. Ini menunjukkan tidak terdapat hubungan yang signifikan antara minat dengan pengalaman mengajar guru Sains dalam pelaksanaan DLP. Maka dapatlah disimpulkan bahawa Ho3 adalah diterima kerana tidak terdapat hubungan yang signifikan antara minat dengan pengalaman mengajar guru sains dalam perlaksanaan DLP.

Secara umumnya dapatlah diringkaskan bahawa tahap kesediaan guru adalah sederhana dari segi kemahiran dan minat manakala tinggi dari segi pengetahuan dalam melaksanakan DLP. Dapatan juga menunjukkan tidak terdapat hubungan yang signifikan antara kemahiran, pengetahuan dan minat dengan pengalaman dalam pelaksanaan DLP. 


\section{PERBINCANGAN}

Kajian ini mengkaji faktor pengetahuan, kemahiran dan minat dalam melaksanakan DLP di sekolah rendah. Secara umumnya, guru-guru menpunyai pengetahuan, kemahiran dan minat yang sederhana dalam melaksanakan DLP di sekolah masing-masing. Bagi memastikan kemahiran, pengetahuan dan minat guru-guru terhadap pelaksanaan ini, guru-guru seharusnya diberikan sebanyak mungkin input bagi memastikan keberkesanan pelaksanaan ini. Namun, realitinya, guru-guru berhadapan dengan situasi yang berbeza apabila mula mengajar di sekolah. Ini mungkin disebabkan faktor-faktor lain seperti faktor persekitaran, keadaan bilik darjah, kelakuan murid-murid, sikap pentadbir dan lain-lain lagi yang mempengaruhi guru-guru dalam melaksanakan sesi PdPc di sekolah. Keadaan ini bertambah rumit apabila guru-guru kekurangan sumber yang mencukupi untuk dijadikan rujukan tentang pelaksanaan ini.

Pengajaran DLP secara langsung atau tidak langsung membawa pelbagai cabaran dan masalah kepada guru-guru. Justeru itu, hasil dapatan kajian ini memberikan pelbagai implikasi kepada pihak-pihak tertentu. Diantaranya ialah guru, pihak pentadbir, pihak Pejabat Pelajaran Daerah (PPD), pihak Jabatan Pelajaran Negeri (JPN) serta pihak Bahagian Pembangunan Kurikulum (BPK). Kesemua pihak ini perlu bekerjasama dan mengembleng tenaga dalam mencari jalan penyelesaian bagi memudahkan guru-guru untuk melaksanakan DLP dalam PdPc.

Subjek Sains merupakan subjek teras yang dirasakan penting dalam era teknologi masa kini. Murid-murid perlu digalakkan untuk meminati subjek ini. Oleh yang demikian, guru-guru perlu mempunyai tahap kesediaan yang tinggi bagi memastikan input yang diperolehi oleh murid-murid juga tinggi.

Justeru itu, dapatan kajian ini mendapati tidak terdapat hubungan yang signifikan antara pengetahuan, kemahiran dan minat guru-guru dengan pengalaman mengajar mereka disekolah masing-masing. Ini menunjukkan guru berpengalaman lama juga perlu diberikan pendedahan yang lebih mendalam bagi memastikan mereka dapat melaksanakan DLP ini dengan lebih berkesan.

Oleh itu, penyelidik berharap dapatan kajian ini dapat membantu pihak-pihak tertentu terutamanaya guru Sains dalam melakukan penambahbaikan dan mencari langkah yang efektif untuk melaksanakan DLP dalam PdPc di sekolah rendah. Tahap kesediaan guru yang tinggi dapat membantu guru-guru Sains dalam melaksanakan DLP dengan baik dan Berjaya.

Penyelidik juga berharap dapatan kajian ini dapat membantu pihak kementerian untuk menyediakan lebih banyak kursus-kursus yang bersesuai dalam memastikan pelaksanaan ini berjaya. Melalui kursus-kursus yang dijalankan sekaligus dapat meningkatkan pengetahuan, kemahiran dan minat guru melaksankan DLP ini. Sehubungan itu, pihak PPD, JPN dan Kementerian Pendidikan juga perlu bekerjasama dalam menyediakan sumber-sumber yang penting bagi keperluan guru di sekolah. 


\section{KESIMPULAN}

Secara keseluruhannya, kajian ini mengkaji tahap kesediaan guru Sains dari segi pengetahuan, kemahiran dan minat dalam melaksanakan DLP di sekolah rendah dengan faktor demografi iaitu pengalaman mengajar guru. Hasil dapatan penyelidik mendapati tidak terdapat hunbungan yang signifikan antara tahap kesediaan guru dan pengalaman mengajar di sekolah rendah.

Subjek Sains di sekolah rendah merupakan subjek teras yang perlu dikuasai oleh semua murid. Kemahiran guru juga amat berkait rapat dengan pengetahuan Sains. Dalam era teknologi dan globalisasi, guru-guru perlu bersedia dengan kemahiran-kemahiran yang mencukupi seperti penguasaan bahasa Inggeris yang baik dan penggunaan istilah Sains dalam bahasa Inggeris dengan betul dan tepat. Melalui kemahiran yang ada pada seseorang guru, ianya dapat melahirkan generasi yang mampu berdaya saing di mata dunia. Selain itu, pengalaman guru adalah satu aset yang bernilai semasa mengharungi cabaran dalam pelaksanaan DLP yang mula diperkenalkan pada tahun 2016. Hal ini perlu dipandang serius kerana guru adalah pemacu yang amat penting bagi pencapaian pelajar. Para pelajar merupakan golongan utama yang menerima kesan daripada pelaksanaan DLP ini.

Oleh yang demikian, tahap kesediaan guru iaitu pengetahuan, kemahiran dan minat guru Sains perlu dimantapkan agar DLP berjaya dilaksanakan dalam subjek Sains di sekolah rendah.

\section{RUJUKAN}

Ahmad Puad Aris (2005). Kajian Permasalahan Kesediaan Guru Sains Tingkatan Dua Mengajar Dalam Bahasa Inggeris di Daerah Pontian. UTM : Sarjana Muda

Chew Fong Peng (2008). Pengajaran Sains dan Matematk Dalam Bahasa Inggeris (PPSMI) : Penerimaan dan Kesannya Terhadap Status Bahasa Melayu. www. myjournal.my/filebank/published_article/14562/Art_4.PDF

Creswell, J. W. (2010). Educational research - planning, conducting, and evaluating quantitative and qualitative research (4th Ed.). New Jersey: Pearson Merril Prentice Hall.

Guncheng Anak Banter (2010). Persepsi Guru-guru Sekolah Rendah Terhadap Pengajaran dan Pembelajaran Sains dan Matematik Dalam Bahasa Inggeris di Daerah Serian, Sarawak. UUM.

https://ms.wikipedia.org/wiki/Guru. Diakses 16 September 2017 (9.18pm)

https://www.bharian.com.my/node/15252. Akses 25.10.2017

http://www.moe.gov.my/image/pekeliling/2015/circularfile_file_001343_pdf. Diakses pada 16 September $2017(9.47 \mathrm{pm})$

jpnselangor.moe.gov.my/v4/images/PDF/Soalan\%201azim\%20DLP20versi\%20

2.0\%20(2015).pdf. Diakses pada 16 September 2017 (1.00pm).

Kalpana Devi (2016). Penerimaan Guru Sains Terhadap Pelaksanaan Kemahiran Berfikir Aras Tinggi (KBAT) di Sekolah Rendah. Universiti Pendidikan Sultan Idris. 
Krejcie, R. V. dan Morgan, D. W. (1970). Determining Sample Size For Research Activities. Educational and Psychological Measurement, 30(3), 607-610.

Noraini (2010). Penyelidikan Dalam Pendidikan. Kuala Lumpur: McGraw Hill.

Norashid Othman \& Hamzah Md Omar (2014). Beban tugas dan motivasi pengajaran guru di Sekolah Menengah Daerah Ranau. Jurnal Pemikir Pendidikan.Vol. 5, pp35-57.

Norisah (2016). Penerimaan Guru Bahasa Melayu Sekolah Rendah terhadap Penggunaan Pengajaran Secara Maya (VLE). Universiti Pendidikan Sultan Idris.

Norazilawati Abbdulah, Noraini Mohd Noh, Mahizer Hamzah, Nik Azmah Nik Yusuf, Rumaizah Omar (2014). Kesediaan Guru Sains dan Matematik Dalam Pelaksanaan Kurikulum Standard Sekolah Rendah. Journal Pendidikan Sains dan Matematik Malaysia.

Rosni Zamuddin dan Siti Fatihah (2010). Kesediaan Guru Sekolah Menengah Di Daerah Kota Bharu Dalam Melaksanakan Sistem Penilaian Prestasi Pelajar Berasaskan Sekolah. Fakulti Pendidikan, Universiti Teknologi Malaysia.

Seth Bin Sulaiman dan Umi Mardhiah Binti Abu Bakar (2010). Kesediaan Bakal Guru Sains Untuk Mengajar Dalam Bahasa Inggeris. Satu Tinjuan ke Atas Pelajar Tahun Akhir Fakulti Pendidikan. Fakulti Pendidikan, UTM.

Siti Sarah. (2015). Aplikasi komputer dalam kajian linguistik. Fakulti Sains Sosial,Universiti Kebangsaan Malaysia.

Soodak, L. \& Podell, D. 1996. Teacher Efficacy: Toward the Understanding of a Multifaceted Construct. Teaching and Teacher Education 12: 401-411.

Suhaimi Bin Hj Muhamad (2008). Tahap Kesediaan Guru Terhadap Perlaksanaan Model Pengajaran Simulasi Bagi Mata Pelajaran Pendidikan Islam. Master Thesis, UTM.

Suriana Ismail (2012). Kesediaan Guru Terhadap Pelaksanaan mata Pelajaran Reka Bentuk dan Teknologi (RBT) Sekolah Rendah di Malaysia.

Syuhada Choo Abdullah (2008). Penguasaan Bahasa Inggeris Guru Sains, Matematik Wallace, M.J (1991). Trainning Foreign Language Teachers. Cambridge : Cambridge University Press.

www.malaysiakini.com/news/108063. Diakses pada 24 September 2017.

www.utusan.com.my/pendidikan/program-rintis-dlp-bermula-1.178216. Diakses pada 16 September 2017 (11.49pm)

Zarina Abdul Rashid (2016). Tahap Kesediaan Dalam Aspek Pengetahuan dan Keperluan Latihan Berfokuskan Aplikasi KBAT. Universiti Tun Hussien Onn Malaysia : Ijazah Sarjana Pendidikan. 